\title{
Deskripsi Pola Asuh Orang Tua Pada Anak Usia Prasekolah Ditaman Kanak-Kanak Pembina Se Kota Pekanbaru
}

\author{
Pratiwi Gasril $^{*}$, Hayana ${ }^{2}$ \\ ${ }^{1}$ Keperawatan, Universitas Muhammadiyah Riau \\ ${ }^{2} I$ Imu Kesehatan Masyarakat, STIKes Hangtuah Pekanbaru \\ *Email: pratiwi@umri.ac.id
}

\begin{abstract}
Abstrak
Pola asuh merupakan interaksi anak dan orang tua dalam mendidik, membimbing, dan mendisplinkan serta melindungi anak untuk mencapai kedewasaan anak yang sesuai dengan norma-norma yang ada dalam masyarakat, oleh karena itu tujuan dari penelitian ini adalah untuk mengetahui gambaran pola asuh orang tua pada anak usia prasekolah. Metode penelitian ini adalah deskriptif korelasi dengan pendekatan cross sectional yang dilakukan terhadap 78 responden. Tekhnik pengambilan sampel menggunakan cara cluster sampling. Analisa yang digunakan adalah analisa univariat, dengan hasil penelitian menunjukkan gambaran pola asuh orang tua pada anak usia prasekolah ditaman kanak-kanak Pembina sekota pekanbaru adalah Permisif 35(44,9\%), Demokratif 31(39,7\%) dan Otoriter 12(15,4\%). Hasil penelitian ini menunjukkan bahwa mayoritas pola asuh orang tua di taman kanak-kanak pembina sekota pekanbaru adalah Permisif.
\end{abstract}

Keyword: Pola Asuh Orang Tua, Anak usia Prasekolah, Taman Kanak-kanak

\section{PENDAHULUAN}

Pola asuh orang tua adalah pola perilaku yang diterapkan pada anak dan bersifat relatif konsisten dari waktu ke waktu. Pola perilaku ini dapat dirasakan oleh anak, dari segi negatif maupun positif (Siswanti, 2006). Orang tua mempunyai peran dan fungsi yang bermacam-macam, salah satunya adalah mendidik anak. Pada dasarnya pola asuh dapat diartikan seluruh cara perlakuan orang tua yang diterapkan pada anak. Banyak ahli mengatakan pengasuhan anak adalah bagian penting dan mendasar, menyiapkan anak untuk menjadi masyarakat yang baik. Terlihat bahwa pengasuhan anak menunjuk kepada pendidikan umum yang diterapkan. Pengasuhan terhadap anak berupa suatu proses interaksi antara orang tua dengan anak. Interaksi tersebut mencakup perawatan seperti dari mencukupi kebutuhan makan, mendorong keberhasilan dan melindungi, maupun mensosialisasi yaitu mengajarkan tingkah laku umum yang diterima oleh masyarakat (Edward, 2006). 
Pendampingan orang tua diwujudkan melalui pendidikan cara-cara orang tua dalam mendidik anaknya. Cara orang tua mendidik anaknya disebut sebagai pola pengasuhan. Interaksi anak dengan orang tua, anak cenderung menggunakan cara-cara tertentu yang dianggap paling baik bagi anak. Disinilah letaknya terjadi beberapa perbedaan dalam pola asuh. Disatu sisi orang tua harus bisa menetukan pola asuh yang tepat dalam mempertimbangkan kebutuhan dan situasi anak, disisi lain sebagai orang tua juga mempunyai keinginan dan harapan untuk membentuk anak menjadi seseorang yang dicita-citakan yang tentunya lebih baik dari orang tuanya (Jas dan Rachmadiana, 2004).

Pola asuh orang tua sangat penting dalam menghadapi masalah pada anak yang sangat mengganggu yang disebabkan oleh ikatan-ikatan kebersamaan dan ikatan emosional yang mengidentifikasi diri mereka sebagai bagian dari keluarga. Pola asuh orang tua pada kehidupan anak tidak hanya mempengaruhi kehidupan tiap individu anak, tetapi juga hubungan antar saudara. Persaingan saudara terutama merupakan masalah peka karena anak tidak hanya membandingkan dirinya dengan saudara kandungnya yang lain melainkan ia juga menilai bagaimana orang tuanya membandingkan dengan saudaranya yang lain. Ini merupakan beban yang berat bagi anak. Kompetisi antar saudara bisa menghasilkan manfaat, tetapi biasanya anak merasa direndahkan oleh orang tuanya yang lebih suka pada anak lain. Berdasarkan permasalahan diatas peneliti tertarik untuk melakukan penelitian dengan tujuan untuk mengetahui gambaran pola asuh orang tua pada anak usia prasekolah di TK Pembina se kota pekanbaru riau.

\section{METODOLOGI PENELITIAN}

Penelitian ini mengggunakan desain Deskriptif Korelatif dengan rancangan Cross Sectional. Metode Pengambilan sampel dalam penelitian ini menggunakan teknik cluster sampling.

Instrumen yang digunakan berupa kuisioner. Analisa yang digunakan adalah analisa univariat digunakan untuk mendapatkan gambaran tentang karakteristik responde. 


\section{HASIL PENELITIAN DAN PEMBAHASAN}

Tabel pola Asuh

\begin{tabular}{lcc}
\hline \multicolumn{1}{c}{ Pola Asuh } & Frekuensi & Persentase \\
\hline - Demokratif & 31 & 39.7 \\
- Permisif & 35 & 44,9 \\
- Otoriter & 12 & 15,4 \\
\hline
\end{tabular}

Tabel 2 diatas menunjukkan pola asuh yang dominan adalah pola asuh Permisif yaitu 35 orang responden $(44,9 \%)$. Berdasarkan hasil penelitian tentang pola asuh orang tua didapatkan hasil bahwa 35 orang responden $(44,9 \%)$ memiliki dengan pola asuh permesif. Hasil penelitian ini sejalan dengan penelitian yang dilakukan oleh Bakri (2013) didapatkan hasil bahwa pola asuh orang tua yang banyak adalah pola asuh permisif sebanyak $57,7 \%$. Gaya pengasuhan yang bersifat permisif biasanya dilakukan oleh orangtua yang terlalu baik, cenderung memberi banyak kebebasan pada anak-anak dengan menerima dan memaklumi segala perilaku, tuntutan dan tindakan anak, namun kurang menuntut sikap tanggung jawab dan keteraturan perilaku anak (Lestari, 2012). Pola asuh orang tua dalam membantu anak untuk mengembangkan disiplin diri adalah upaya orangtua yang diaktualisasikan terhadap penataan lingkungan fisik, lingkungan sosial internal, pendidikan internal dan eksternal, dialog dengan anak-anaknya, suasana psikologis, sosiobudaya, perilaku yang ditampilkan pada saat terjadinya pertemuan dengan anak-anak, kontrol terhadap perilaku anak-anak dan menentukan nilai-nilai moral sebagai dasar berperilaku dan yang diupayakan kepada anak-anak (Shochib, 2010).

Menurut Hurlock (Sarastuti, 2008), pola asuh terbagi ke dalam tiga kategori yaitu: a) pola asuh otoriter; b) pola asuh demokratis; dan c) pola asuh permisif. Pola asuh otoriter memiliki ciri kekuasaan orang tua dominan, anak tidak diakui sebagai pribadi, kontrol terhadap tingkah laku anak sangat ketat dan orang tua menghukum jika anak tidak patuh. Pola asuh demokratis memiliki ciri ada kerjasama antara orang tua-anak, anak diakui secara pribadi, ada bimbingan dan pengarahan dari orang tua, dan ada kontrol dari orang tua yang tidak kaku. Pola asuh permisif memiliki ciri dominasi pada anak, sikap longgar atau kebebasan dari orang tua, tidak ada bimbingan dan pengarahan dari orang tua, kontrol dan perhatian orang tua sangat kurang. Hasil penelitian ini sejalan dengan penelitian Rahman, Mardhiah, Azmidar (2015) dengan hubungan antara pola asuh permisif orangtua dan kecerdasan emosional siswa dengan hasil belajar matematika siswa dengan nilai $\alpha=0,05$ atau $(0,082$ $>0,05)$ dapat disimpulkan bahwa pola asuh permesif oleh orang tua dapat mempengaruhui kecerdasan emosional pada anak. 


\section{KESIMPULAN}

Hasil penelitian ini didapatkan hasil bahwa didapatkan $p$ velue $(0,05)<$ dari $\alpha(0,005)$ dapat disimpulkan terdapat hubungan yang bermakna antara pola asuh terhadap terjadinya sibling rivalry.

\section{DAFTAR PUSTAKA}

Vol THESUN. Faktor Dominan Terjadinya Sibling. 2015;2(2).

Agustin NUR. Hubungan Pola Asuh Dominan Orang Tua Dengan Sibling Rivalry Anak Usia Pra Sekolah. 2013.

Syam S. Hubungan pola asuh orang terhadap kejadian. 2002.

Suhaidah H. Jurnal Keperawatan \& Kebidanan - Stikes Dian Husada Mojokerto. J Keperawatan Kebidanan Stikes Dian Husada Mojokerto. 2017:81-86.

Bakri, F (2013). Gambaran pola asuh orang tua tentang kejadian kriminal pada remaja di lembaga pemasyarakatan kelas i Makassar. Skripsi. Universitas Islam Negeri Alauddin Makassar

Boyse, K. (2007). Sibling Rivalry: Health System. 48(356-361). Diperoleh dari http://www.med.umich.edu/libr/yourchild.sibriv.html.

Boyse, K . (2009). Sibling Rivalry: Health System. 48(356-361). Diperoleh dari http://www.med.umich.edu/libr/yourchild.sibriv.html

Lestari, S (2012). Psikologi Keluarga. Jakarta: Kencana.

Maghfuroh, Lilis. (2014). Hubungan pola asuh orang tua dengan kejadian sibling rivalry pada balita, Vol 1, no. 17., pp 113-120

Rahman, U., Mardhiah \& Azmidar (2015) Hubungan antara pola asuh permisif orangtua dan kecerdasan emosional siswa dengan hasil belajar matematika siswa. Auladuna, VOL. 2 NO. 1 JUNI 2015: 116-130

Rahmawati, Etika. (2013). Hubungan antara sibling rivalry dengan kemampuan penyesuaian sosial anak usia sekolah. Skripsi tidak dipublikasikan.

Rezeki, Sri. (2012). Pengetahuan ibu dan reaksi sibling rivalry pada anak usia prasekolah (3-5 tahun). Skripsi tidak dipublikasikan.

Sarastuti, I (2008) “Kedisiplinan Siswa SMP Ditinjau Dari Pola Asuh Permisif Orangtua”. Skripsi. Semarang: Fakultas Psikologi Universitas Katolik Soegijapranata.

Shochib, M (2010). Pola Asuh Orang Tua. Jakarta: PT RINEKA CIPTA

Susanto A. (2011). Perkembangan anak usia dini. Ed. I. Jakarta: Kencana. Mengatasi persaingan antar saudara kandung pada anak-anak. Jakarta: PT. Elek Media Komputindo

Riyadi, S. \& Sukarmin. (2009). Asuhan keperawatan pada anak. Yogyakarta: Graha Ilmu 